\title{
Potentiostat Electro-Deposited Cuprous Oxide and Cupric Oxide Thin Films for Photovoltaic Use
}

\author{
T. P. Plateau ${ }^{1}$, M. T. Islam ${ }^{1, *}$ and N. Islam ${ }^{2}$ \\ ${ }^{1}$ Department of Materials and Metallurgical Engineering, Bangladesh University of \\ Engineering and Technology, Dhaka, Bangladesh. \\ *Email: tauhid.buet11@gmail.com \\ Phone: +15734661176 \\ ${ }^{2}$ Department of Electrical and Electronic Engineering, East West University, Dhaka, \\ Bangladesh. \\ Phone: +8801686090330
}

\begin{abstract}
To withstand the rising demand for energy while fuel and chemical energy are becoming rare, the development in the production of solar energy has become a necessity. There is a variety of solar cells; among them, thin-film photovoltaics is more popular because of low-cost production and good-efficiency. Nowadays, copper oxide has become popular to make thin film layers like CZTS, CIGS, etc. Unfortunately, the efficiency of these thin films is less than $20 \%$. In order to obtain better efficacy, an investigation of the layers of thin films is needed. This research discussed the properties of copper and its oxides. In case of making the thin film layers, potentiostat electro-deposition was the chosen method where bath composition of $\mathrm{CuSO}_{4} .5 \mathrm{H}_{2} \mathrm{O}$ solution, temperature, time, potential difference were the variable parameters. The best-deposited layers were obtained in $0.2 \mathrm{M}$ concentration, 40 minutes, $-0.5 \mathrm{~V}$ potential difference and $65^{\circ} \mathrm{C}$. Hence, physical properties like thickness and hardness, and characterisation properties like X-ray diffractometry (XRD), scanning electron microscopy (SEM), UV-Vis spectrometry are observed to compare cupric oxide $(\mathrm{CuO})$ and cuprous oxide $\left(\mathrm{Cu}_{2} \mathrm{O}\right)$ thin films. $\mathrm{CuO}$ thin film shows better stability and rigidity than the $\mathrm{Cu}_{2} \mathrm{O}$ thin film. But the thin film layer of cuprous oxide illustrates good homogeneity and nodular form. From the test mentioned above data, band gap has been measured for each deposited film, and the $\mathrm{CuO}$ thin film layer is raked out having a better band energy gap than the $\mathrm{Cu}_{2} \mathrm{O}$ thin film layer.
\end{abstract}

Keywords: Photovoltaic; thin film; potentiostat electro-deposition; band energy gap.

\section{INTRODUCTION}

Conventional crystalline silicon has been used to make solar cells, but they are cost efficient. As a result, people are uninterested in using silicon-based solar panels. In case of reducing cost, thin film photovoltaic cell introduces us with a great posterior. Nowadays, organic synthesised perovskite materials are using to make a high-efficient absorber layer for solar usage $[1,2]$. But the process of making organic photovoltaic is complex so that, the total production cost is high.

On the contrary, thin film solar cells, such as CZTS (copper-zinc-tin-sulfur) and CIGS (copper-indium-gallium-sulfur/selenium), can be easily fabricated. So, the overall production cost is lower than the perovskite solar cells [3]. The cost mainly depends on the materials that are used to manufacture the absorber layer. In order to develop the 
matrix of different materials of the photovoltaic, rare earth metals and less available materials like cadmium, indium, selenium, titanium, and tellurium can be used to fabricate thin film solar cell. Different oxides such as $\mathrm{ZnO}, \mathrm{CuO}$ etc. and sulfides such as $\mathrm{CdS}, \mathrm{ZnS}, \mathrm{Cu}-\mathrm{In}-\mathrm{S}$, are also used to make thin films. The most popular thin film absorber layers of photovoltaics are CIGS and CZTS. The available CZTS and CIGS solar cells in the market offer a total efficiency of $9.5 \%$ and $15 \%$ respectively. But the best efficiency achieved in the laboratories is $20 \%$ for the CIGS solar cells and $14 \%$ for CZTS solar cells. The photovoltaic-efficiency depends on the band gap of material because the band gap is dependent on the absorbance of the oxide or sulfide layers of the thin film [4]. According to "Shockley-Queisser limit", the best efficiency 33.7\% for CZTS can be achieved while the band gap will be $1.4 \mathrm{eV}[5,6]$. So, there is a huge chance to improve today's CZTS photovoltaics absorber layers. In order to achieve higher efficiency, the mixed layer of oxides and sulfides of copper, zinc, tin were fabricated with various type of deposition methods (such as, chemical vapor deposition, physical vapor deposition, sputtering, atomic layer deposition, ion beam, laser melting, fused deposition modelling etc.) and different thickness $[7,8]$.

In recent research, the higher efficiency has been observed using a potentiostat electro-deposition method for making the thin film layers of oxides $[9,10]$. Likewise, the CZTS or CIGS thin-film photovoltaic can be developed by electro-deposition method because it's easy production procedure and cost-saving method. Now, the primary element of CZTS or CIGS thin-film photovoltaics is copper or deposited copper oxide which plays a vital role for measuring the band energy gap of the absorber layer. Copper is a divalent element and so it has two types of oxide: cuprous oxide $\left(\mathrm{Cu}_{2} \mathrm{O}\right)$ and cupric oxide $(\mathrm{CuO})$. Therefore, in the case of making CZTS or CIGS solar cell, each of the copper oxides possesses different characterization properties and band energy gap as well as shows different efficiency. This research targets to develop and analyse the characteristics of $\mathrm{Cu}_{2} \mathrm{O}$ and $\mathrm{CuO}$ thin films and to draw a comparison between them according to the stability, homogeneity, efficacy, absorbance and band energy gap.

\section{EXPERIMENTAL PROCEDURES}

\section{Material and Method}

From 1839 when Alexandre Edmond Becquerel first observed the photovoltaic effect, scientists are trying to catch more energy and in the journey of acquiring energy one thing should be kept in mind that is the cost of production. There are several parts of a photovoltaic cell; among them, the absorber layer is one of the most costly parts. In this research, electrochemical deposition has been chosen because of its easiness, flexibility and quickness. To be more specific, potentiostat electro-deposition was done $[2,11]$. The potentiostat method was selected, and a constant current density was supplied. Three electrode system was consolidated where the reference electrode was $\mathrm{Ag}+/ \mathrm{AgCl}$ electrode; the other electrodes were copper. Looking forward to using the cheap and available material, copper and its oxides were chosen for the research. Copper is not only cheap but also non-toxic, good absorber of visible light and most importantly copper is a perfect material for potentiostat electro-deposition [12].

The solution for the research was $\mathrm{CuSO}_{4} .5 \mathrm{H}_{2} \mathrm{O}$ and $5 \%$ Nital was used for etching. Four parameters (bath composition, temperature, potential difference and time) were altered and other parameters (current density, $\mathrm{pH}$ value, electrocatalyst, heating rate etc.) remained unchanged. For temperature control, a heat bath was used using magnetic 
stirring. Then the substrates were used in three electrode system as shown in Figure 1. Different bath composition $(0.1 \mathrm{M}, 0.2 \mathrm{M}, 0.3 \mathrm{M}, 0.4 \mathrm{M}, 0.5 \mathrm{M})$ of $\mathrm{Cu}_{2} \mathrm{SO}_{4} .5 \mathrm{H}_{2} \mathrm{O}$ were used to deposit $\mathrm{Cu}_{2} \mathrm{O}$ and $\mathrm{CuO}$ thin films. For both the oxides, best-deposited films were observed in $0.2 \mathrm{M}$ and $0.3 \mathrm{M}$ bath composition. Thus further investigation continued with $\mathrm{Cu}_{2} \mathrm{O}$ and $\mathrm{CuO}$ thin film deposited from $0.2 \mathrm{M}$ and $0.3 \mathrm{M}$ baths. Table 1 shows the different parameters experimented in this work.

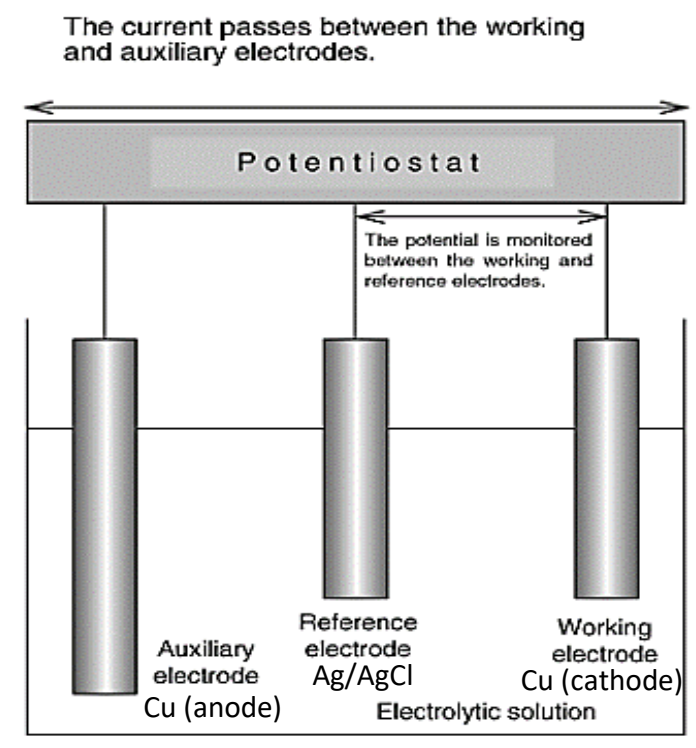

Figure 1. Schematic diagram of experimental setup.

\section{Hardness and Thickness Measurement}

Hardness properties were measured by micro-indentation. Shimadzu microhardness testing machine was used at Vickers hardness scale. The load was $100 \mathrm{Kg}-\mathrm{f}(0.98 \mathrm{KN})$ and duration of load applying time was 10 to 15 seconds. After deposition, thickness was measured by the metallographic image. For the metallographic testing, samples are cut into small pieces and mounted in Bakelite plastic. Then, the sample is polished by the emery papers of 120,180,320, 600, 800, 1200 and 1500 respectively and finally in the spinning polisher. Then the microstructures were taken to measure the thickness. But the film thickness was similar and perfect thickness could not be measured. So, to get more accurate thickness measurement, the ultrasound sensor machine was used. This machine can evaluate the real thickness of the thin films.

\section{Characterisation Test}

After getting the good deposited thin film of $\mathrm{CuO}$ and $\mathrm{Cu}_{2} \mathrm{O}$, some characterization tests were done such as scanning electron microscopy (SEM) to observe the sample's surface topography and composition, $\mathrm{x}$-ray diffractometry (XRD) to determine the phases present in the deposited films, UV- vis Spectrometry to determine the absorbance of the deposited films at the wavelength range of 200-1100 $\mathrm{nm}$. The SEM image processing was done by SEM JSM-6490 version 1.0 machine. The pixel size was 0.00002 and the computer software was Micron Maker Sum. Images observed in 10000, 20000 and 30000 magnification. X-ray diffractometry test was done by "RIGAKU Ultima IV X-ray 
diffractometer". Band-gap was calculated according to the absorption measured by UV spectrophotometer absorbance at a fixed recording absorption spectrum.

Table 1. Variable parameters.

\begin{tabular}{|c|c|c|c|}
\hline $\begin{array}{l}\text { Bath Composition } \\
\text { (M) } \mathrm{CuSO}_{4} .5 \mathrm{H}_{2} \mathrm{O}\end{array}$ & $\begin{array}{c}\text { Potential difference } \\
(\mathrm{V})\end{array}$ & Time (min) & Temperature $\left({ }^{\circ} \mathrm{C}\right)$ \\
\hline \multirow{12}{*}{ ( } & \multirow{7}{*}{ 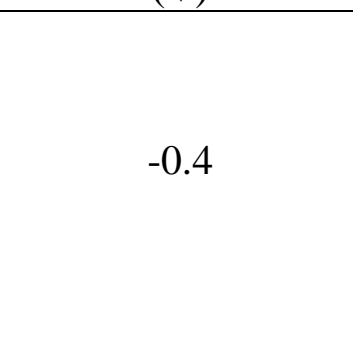 } & \multirow{3}{*}{35} & 60 \\
\hline & & & 65 \\
\hline & & & 70 \\
\hline & & \multirow{3}{*}{40} & 60 \\
\hline & & & 65 \\
\hline & & & 70 \\
\hline & & \multirow{4}{*}{35} & 60 \\
\hline & \multirow{5}{*}{-0.5} & & 65 \\
\hline & & & 70 \\
\hline & & & 60 \\
\hline & & \multirow[t]{2}{*}{40} & 65 \\
\hline & & & 70 \\
\hline \multirow{12}{*}{0.3} & \multirow{6}{*}{-0.4} & \multirow{4}{*}{35} & 60 \\
\hline & & & 65 \\
\hline & & & 70 \\
\hline & & & 60 \\
\hline & & \multirow[t]{3}{*}{40} & 65 \\
\hline & & & 70 \\
\hline & \multirow{6}{*}{-0.5} & & 60 \\
\hline & & \multirow[t]{3}{*}{35} & 65 \\
\hline & & & 70 \\
\hline & & & 60 \\
\hline & & \multirow[t]{2}{*}{40} & 65 \\
\hline & & & 70 \\
\hline
\end{tabular}

\section{RESULTS AND DISCUSSION}

\section{Micro-Hardness Measurement}

The observed values of Vickers hardness test of $\mathrm{Cu}_{2} \mathrm{O}$ and $\mathrm{CuO}$ thin deposited films respectively, are listed in Table 2 and Table 3 respectively. From the data, it is inferred that $\mathrm{CuO}$ film shows a greater hardness than $\mathrm{Cu}_{2} \mathrm{O}$ film. In parallel, greater hardness indicates high stability. Therefore, $\mathrm{CuO}$ is more hard and stable than that of $\mathrm{Cu}_{2} \mathrm{O}$. The interatomic bond between the atoms of copper and oxygen enhances significantly in $\mathrm{CuO}$ through electro-deposition technique. In electrodeposition, the copper (II) ion exerts two electrons which are occupied in pairing with the oxygen ions. Copper (I) ion exert one electron and two of these ions tried to be connected with one single ion of oxygen. The bond strength of $\mathrm{Cu}_{2} \mathrm{O}$ is less than the bond strength of $\mathrm{CuO}$. So, it is highly important to use $\mathrm{CuO}$ instead of $\mathrm{Cu}_{2} \mathrm{O}$ in case of making an absorber layer for copper-based thin film solar cell. 
Table 2. Micro-hardness of $\mathrm{Cu}_{2} \mathrm{O}$ thin film.

\begin{tabular}{cccc}
\hline $\begin{array}{l}\text { Concentration } \mathrm{CuSO}_{4} .5 \mathrm{H}_{2} \mathrm{O} \\
(\mathrm{M})\end{array}$ & $\begin{array}{c}\text { Voltage } \\
(\mathrm{V})\end{array}$ & $\begin{array}{c}\text { Temperature } \\
\left({ }^{\circ} \mathrm{C}\right)\end{array}$ & $\begin{array}{c}\text { Hardness } \\
(\mathrm{HV})\end{array}$ \\
\hline 0.2 & -0.4 & 65 & 26.23 \\
0.3 & -0.4 & 60 & 63.46 \\
0.2 & -0.5 & 65 & 48.45 \\
0.3 & -0.5 & 60 & 78.77 \\
\hline
\end{tabular}

Table 3. Micro-hardness Values of $\mathrm{CuO}$ thin Film

\begin{tabular}{cccc}
\hline $\begin{array}{l}\text { Concentration } \mathrm{CuSO}_{4} .5 \mathrm{H}_{2} \mathrm{O} \\
(\mathrm{M})\end{array}$ & $\begin{array}{c}\text { Voltage } \\
(\mathrm{V})\end{array}$ & $\begin{array}{c}\text { Temperature } \\
\left({ }^{\circ} \mathrm{C}\right)\end{array}$ & $\begin{array}{c}\text { Hardness } \\
(\mathrm{HV})\end{array}$ \\
\hline 0.2 & -0.4 & 65 & 47.81 \\
0.3 & -0.4 & 60 & 163.96 \\
0.2 & -0.5 & 65 & 84.01 \\
0.3 & -0.5 & 60 & 126.91 \\
\hline
\end{tabular}

\section{Thickness Measurement}

It is inferred from Table 4 and Table 5 that the films were not deposited uniformly. So, a variety of thickness was observed. Moreover, average thickness values of $\mathrm{CuO}$ thin film is higher than the $\mathrm{Cu}_{2} \mathrm{O}$ thin film. Therefore, $\mathrm{CuO}$ deposited thin film gives a more stable coating than that of $\mathrm{Cu}_{2} \mathrm{O}$ thin film. The atomic structure of $\mathrm{Cu}_{2} \mathrm{O}$ is larger than the atomic structure of $\mathrm{CuO}$. From the thickness data, it is clearly observed that the layer of $\mathrm{Cu}_{2} \mathrm{O}$ is less than the layer of $\mathrm{CuO}$. That means, less amount of $\mathrm{Cu}_{2} \mathrm{O}$ atoms are present in the layer of $\mathrm{Cu}_{2} \mathrm{O}$ and a higher number of atoms are present in the $\mathrm{CuO}$ layer which makes the compact and hard layer of $\mathrm{CuO}$.

Table 4. Coating Thickness of $\mathrm{Cu}_{2} \mathrm{O}$ Film

\begin{tabular}{lccc}
\hline $\begin{array}{l}\text { Concentration } \\
\mathrm{CuSO}_{4} .5 \mathrm{H}_{2} \mathrm{O}(\mathrm{M})\end{array}$ & $\begin{array}{c}\text { Voltage } \\
(\mathrm{V})\end{array}$ & $\begin{array}{c}\text { Temperature }\left({ }^{\circ} \mathrm{C}\right) \\
\begin{array}{c}\text { Average thickness } \\
(\mu \mathrm{m})\end{array}\end{array}$ & $\begin{array}{c}2.58 \\
0.2\end{array}$ \\
0.3 & -0.4 & 65 & 6.52 \\
0.2 & -0.4 & 60 & 3.24 \\
0.3 & -0.5 & 65 & 5.8 \\
\hline
\end{tabular}

Table 5. Coating thickness of CuO Film

\begin{tabular}{llll}
\hline $\begin{array}{l}\text { Concentration } \\
\mathrm{CuSO}_{4} .5 \mathrm{H}_{2} \mathrm{O}(\mathrm{M})\end{array}$ & $\begin{array}{l}\text { Voltage } \\
(\mathrm{V})\end{array}$ & Temperature $\left({ }^{\circ} \mathrm{C}\right)$ & $\begin{array}{l}\text { Average thickness } \\
(\mu \mathrm{m})\end{array}$ \\
\hline 0.2 & -0.4 & 65 & 7.4 \\
0.3 & -0.4 & 60 & 18.44 \\
0.2 & -0.5 & 65 & 3.625 \\
0.3 & -0.5 & 60 & 5.0 \\
\hline
\end{tabular}




\section{Characterisation of Thin Film}

Electron microscopy results are shown in Figure 2 and Figure 3; which represent the SEM images of $\mathrm{Cu}_{2} \mathrm{O}$ thin film and $\mathrm{CuO}$ thin film. From the figures, it is depicted that $\mathrm{Cu}_{2} \mathrm{O}$ film has good grain refinement and homogeneity than that of $\mathrm{CuO}$ film. It is also observed that the particles of $\mathrm{Cu}_{2} \mathrm{O}$ are loosely bonded. On the other hand, the particles of $\mathrm{CuO}$ surface has densely collaborated with each other. For, different bath composition, $\mathrm{CuO}$ always possessed better surface roughness and good planarity.

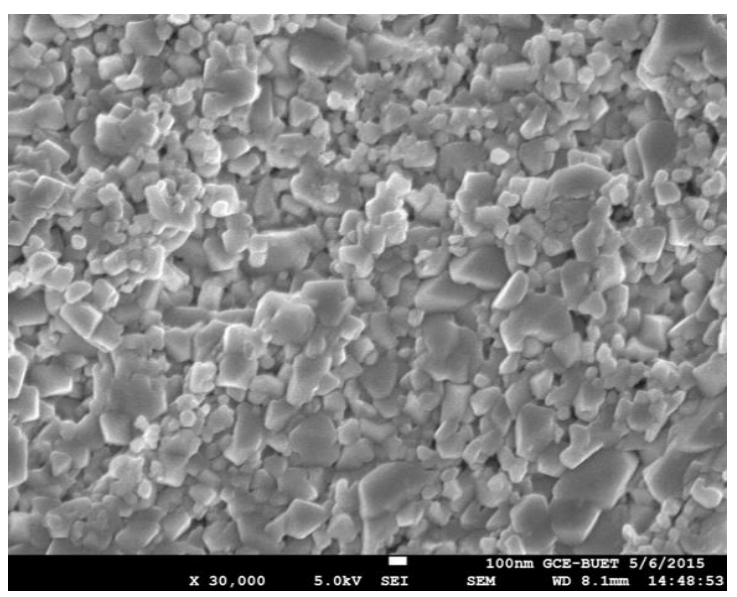

(a)

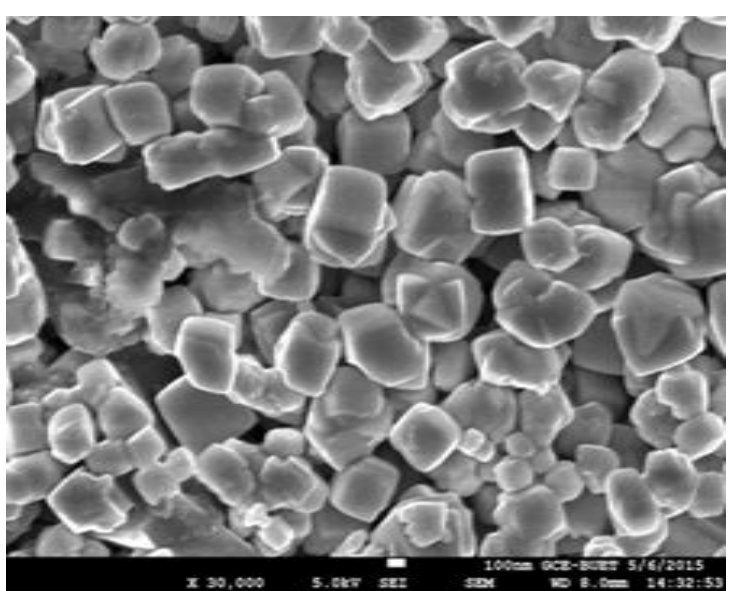

(b)

Figure 2. SEM images of $\mathrm{Cu}_{2} \mathrm{O}$ thin film; (a) deposited from $0.2 \mathrm{M}$ bath composition, (b) deposited from $0.3 \mathrm{M}$ bath composition.

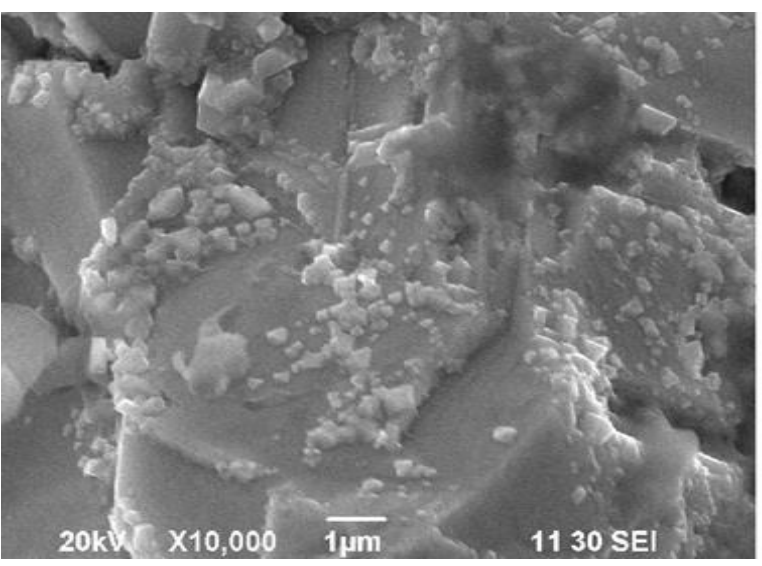

(a)

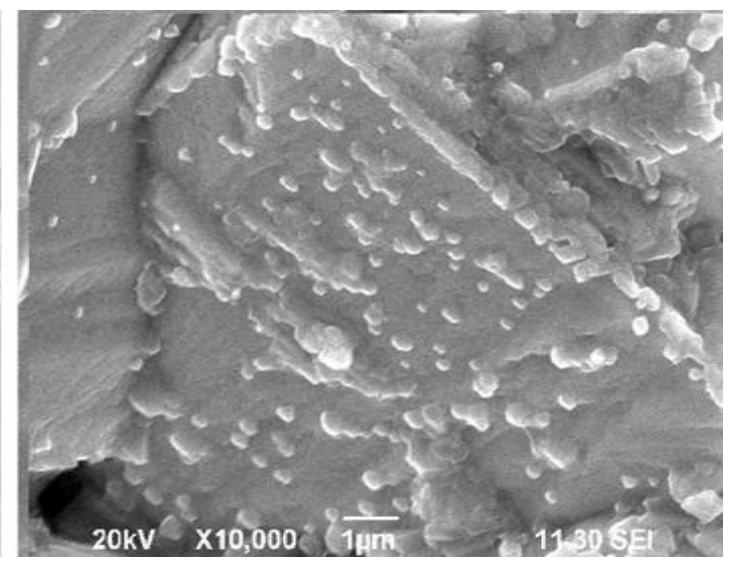

(b)

Figure 2. SEM images of $\mathrm{CuO}$ thin Film; (a) deposited from $0.2 \mathrm{M}$ bath composition, (b) deposited from $0.3 \mathrm{M}$ bath composition.

Figure 3(a) and 3(b) depicts the results of X-ray diffractometry of $\mathrm{Cu} 2 \mathrm{O}$ and $\mathrm{CuO}$ thin films, respectively. The intensity versus $2 \theta$ graphs shows the evidence of thin films. The intensity peaks of the films assure the penetration of X-ray through the film to the substrate. The $\mathrm{Cu}$ peaks were observed because of the substrate copper metal, and the oxides ensured the presence of the thin film absorber layer. Moreover, the peaks illustrated the existence of crystallinity of the thin film. There is no intermetallic phase is 
observed from the XRD analysis. There are no peak broadening phenomena observed in the XRD graphs, that means no non-uniform lattice strain was formed [13, 14]. From the intensity values, it is empirically observed that the $\mathrm{Cu}_{2} \mathrm{O}$ has higher weight percentage in the sample than the $\mathrm{CuO}$. Thus, the thinner layer of $\mathrm{Cu}_{2} \mathrm{O}$ has a higher mass than the thicker layer of $\mathrm{CuO}$.

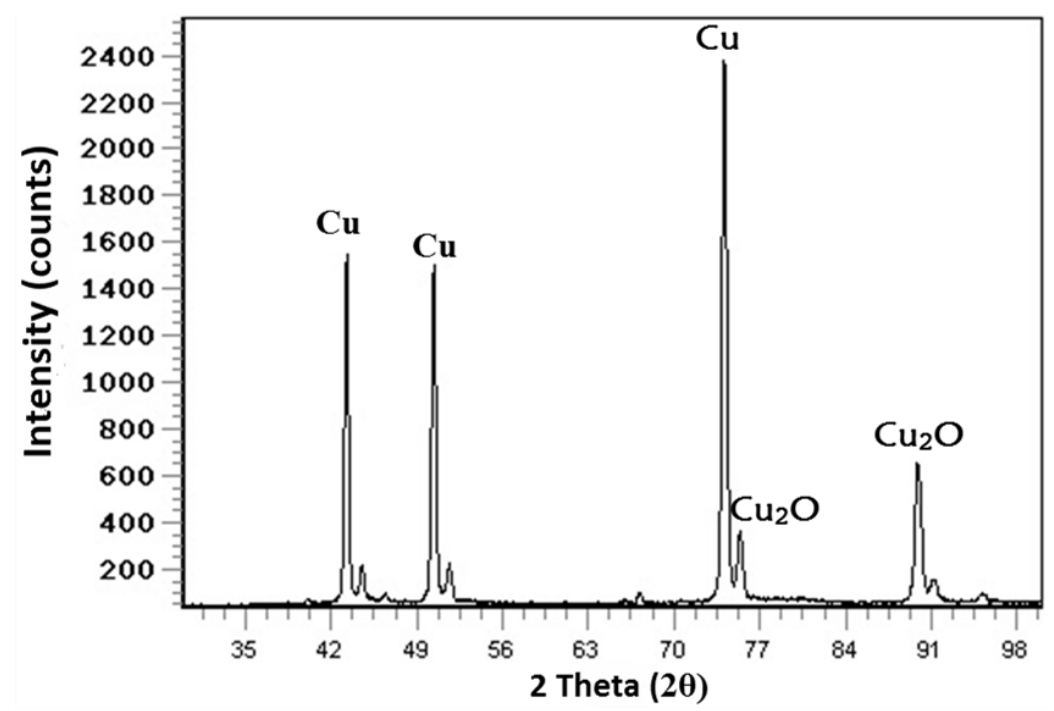

(a)

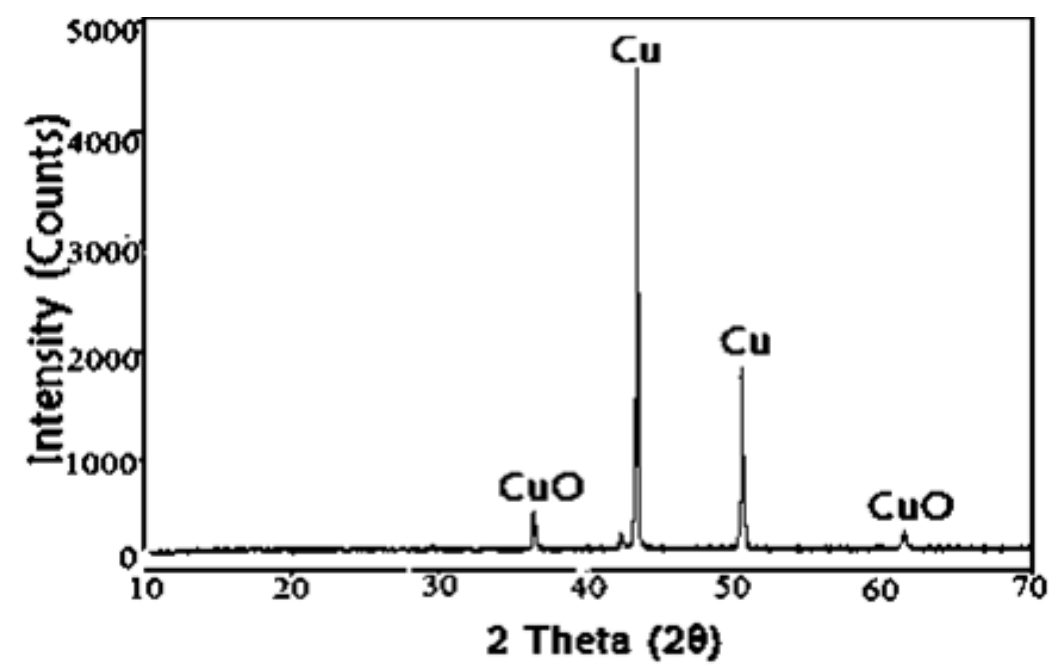

(b)

Figure 3. XRD scan of (a) $\mathrm{Cu}-\mathrm{Cu}_{2} \mathrm{O}$ and; (b) $\mathrm{Cu}-\mathrm{CuO}$ thin film.

Absorption of ultraviolet ray according to the wavelength, was measured by UVVis spectrometry. The graphical representation of the measured data is illustrated in Figure 4(a) and 4(b). From the data values, the band gap was calculated by absorption energy-related formulas [15]. Moreover, Figure 5(a) and 5(b) are illustrated to measure the band gap value. Here, absorption coefficient $\alpha=2.303 \mathrm{~A} / \mathrm{d}$ where planks constant, $\mathrm{h}$ $=6.626 \times 10^{-34}$ light velocity, $\mathrm{c}=3 \times 108 \mathrm{~ms}^{-1}$, wavelength $=\lambda$, absorbance $=\mathrm{A}$, thickness $=$ d. This graph is depicted by the average values of different parameters like bath composition, potential difference, time and temperature. From these graphs, the band gap measured for the $\mathrm{Cu}_{2} \mathrm{O}$ thin film is $0.5 \mathrm{eV}$, whereas the band gap for $\mathrm{CuO}$ thin film is 0.9 
$\mathrm{eV}$. The Shockley-Queisser limit and from this graph, it is found that $0.9 \mathrm{eV}$ gives more efficiency than $0.5 \mathrm{eV}$ band gap $[5,16]$. Therefore, $\mathrm{CuO}$ thin films give more efficiency than that of $\mathrm{Cu}_{2} \mathrm{O}$ thin films.

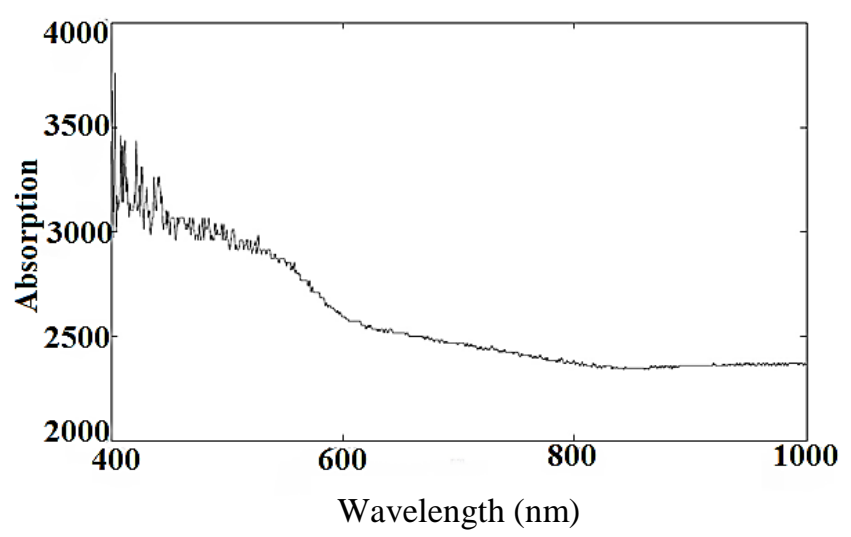

(a)

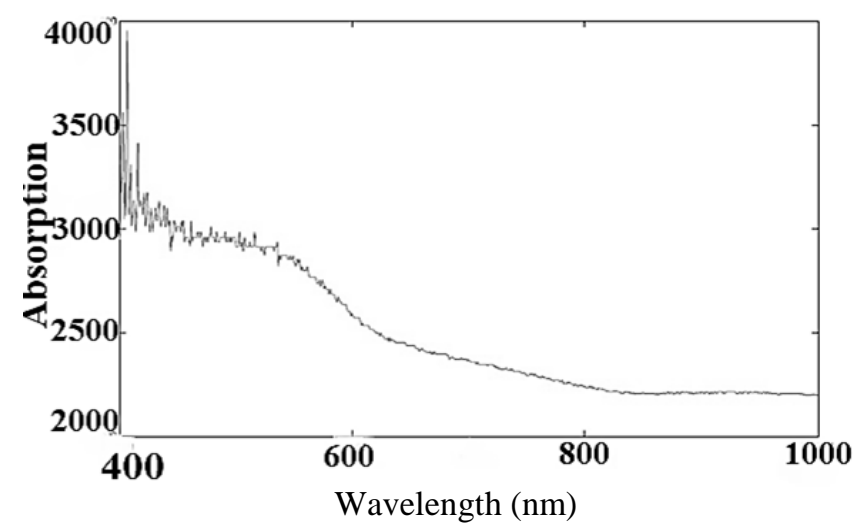

(b)

Figure 4. UV-Vis spectrometry graph of deposited (a) $\mathrm{Cu}_{2} \mathrm{O}$ and; (b) $\mathrm{CuO}$ thin film.

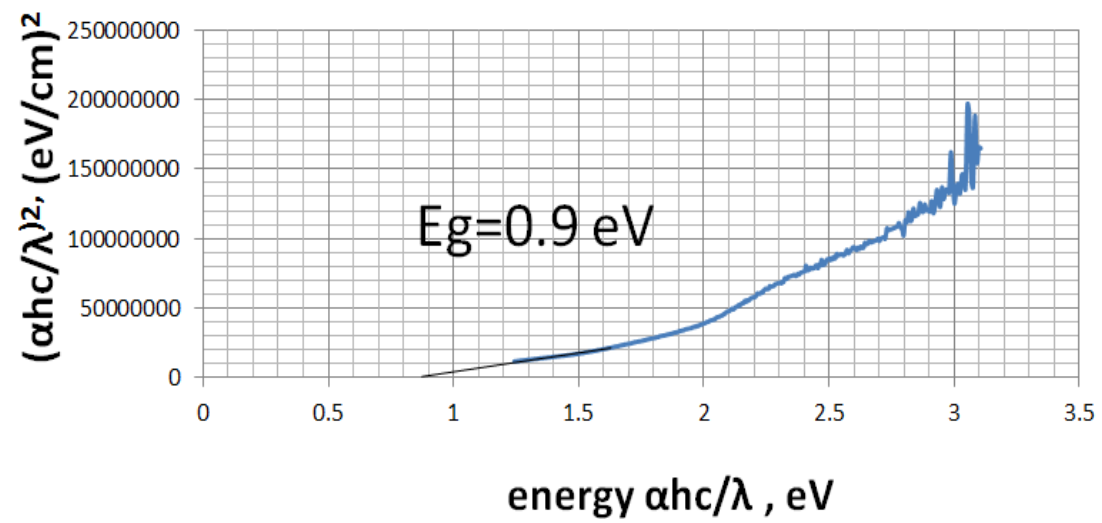

(a) 


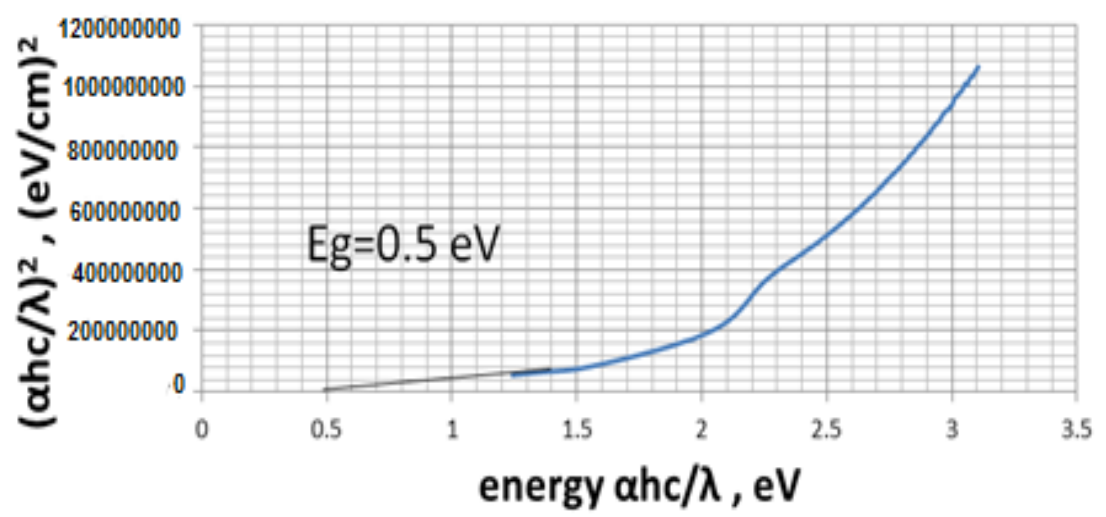

(b)

Figure 6. Band gap measured for (a) $\mathrm{CuO}$ (b) $\mathrm{Cu}_{2} \mathrm{O}$ thin film.

\section{CONCLUSION}

This heuristic research targets to achieve a better thin film of copper oxides. From characterisation tests and measurement of physical properties, a constructive comparison established. Focusing on stability and rigidity, $\mathrm{Cu}_{2} \mathrm{O}$ thin film shows less effective than $\mathrm{CuO}$ thin film. On the contrary, the grain refinement and uniformity of grain size of $\mathrm{Cu}_{2} \mathrm{O}$ thin film is very good. But cupric oxide $(\mathrm{CuO})$ thin film does not depict positively in this case. The most important thing is the efficacy of the thin films as the absorber layer of the photovoltaic cell. Therefore, using $\mathrm{CuO}$ thin film in preparation of CZTS may create a novel future in the field of the photovoltaic cell. Not only CZTS photovoltaics but also this study may have a great impact on the other thin film solar cell which has a thin layer of the copper. This research study also opens a wide door of future materials research for the absorber layer made by very cheap inorganic materials. The upcoming era of inexpensive and non-toxic solar cells will have a stunning beginning by using copper oxide layers. The comparison between the oxides will also help in qualitative assessment for the thin films. This qualitative analysis has been opened a new road to investigate the conventional models and materials of thin films. This unique study indicates a useful technique to improve conventional thin films. In future, several oxides and sulphides of different metals can be observed to mitigate the future demands of highly efficient lowcost solar devices.

\section{ACKNOWLEDGEMENT}

This research group profoundly thanks Dr Rumana Akther Jahan (Senior Scientific Officer, Materials Science Research, Centre for Advanced Research in Sciences, Dhaka University) for giving the scope of using the XRD \& UV Vis and SEM machines, without which the research work would have become unduly lengthened.

\section{REFERENCES}

[1] Heo JH, Im SH, Noh JH, et al. Efficient inorganic-organic hybrid heterojunction solar cells containing perovskite compound and polymeric hole conductors. Nature Photonics 2013; 7: 486.

[2] Mason N. Impact of materials prices on cost of pv manufacture - Part I. Retrieved from http://www.iom3.org/sites/default/files/iom3-corp/Mason\%20SMEET\%2 
02\%20presentation\%2027Feb13.pdf.

[3] Suryawanshi MP, Agawane GL, Bhosale SM, et al. CZTS based thin film solar cells: a status review. Materials Technology 2013; 28: 98-109.

[4] Almosni S, Delamarre A, Jehl Z, et al. Material challenges for solar cells in the twenty-first century: directions in emerging technologies. Science and Technology of Advanced Materials 2018; 19: 336-369.

[5] Shockley W, Queisser HJ. Detailed balance limit of efficiency of p-n junction solar cells. Journal of Applied Physics 1961; 32: 510-519.

[6] Munday JN. The effect of photonic bandgap materials on the Shockley-Queisser limit. Journal of Applied Physics 2012; 112: 064501.

[7] Davis J. Surface Engineering for Wear and Resistance. 1st ed. Ohio: ASM International, 2001.

[8] Leng Y. Materials characterization: introduction to microscopic and spectroscopic methods. 2nd ed. Singapore: John Wiley \& Sons (Asia) Pte Ltd, 2009.

[9] Shin B, Gunawan O, Zhu Y, et al. Thin film solar cell with $8.4 \%$ power conversion efficiency using an earth-abundant $\mathrm{Cu} 2 \mathrm{ZnSnS} 4$ absorber. Progress in Photovoltaics: Research and Applications 2013; 21: 72-76.

[10] Jackson P, Hariskos D, Lotter E, et al. New world record efficiency for $\mathrm{Cu}(\mathrm{In}, \mathrm{Ga}) \mathrm{Se} 2$ thin-film solar cells beyond 20\%. Progress in Photovoltaics: Research and Applications 2011; 19: 894-897.

[11] Perlin J. Let it shine: The 6,000-year story of solar energy. 9th ed. Novato: New World Library, 2013.

[12] Ramanujam J, Singh UP. Copper indium gallium selenide based solar cells - A review. Energy and Environmental Science 2017; 10: 1306-1319.

[13] Johan M, Mohd Suan M, Hawari N, et al. Annealing effects on the properties of copper oxide thin films prepared by chemical deposition. International Journal of Electrochemical Science 2005; 6: 6094-6104.

[14] Mahalingam T, Chitra J, Rajendran S, et al. Potentiostatic deposition and characterization of $\mathrm{Cu} 2 \mathrm{O}$ thin films. Semiconductor Science and Technology 2002; 565: 2-7.

[15] Mkawi EM, Ibrahim K, Ali MKM, et al. Dependence of copper concentration on the properties of $\mathrm{Cu} 2 \mathrm{ZnSnS} 4$ thin films prepared by electrochemical method. International Journal of Electrochemical Science 2013; 8: 359-368.

[16] Ahmed S, Reuter KB, Gunawan O, et al. A high efficiency electrodeposited Cu2ZnSnS4 solar cell. Advanced Energy Materials 2012; 2: 253-259. 